\title{
FACILITIES MANAGEMENT OUTSOURCING: THEORETICAL TRENDS AND EVIDENCE FROM PRACTICE IN NIGERIA AND UNITED KINGDOM
}

\author{
Dubem I. IKEDIASHI ${ }^{a, *}$, Isaac A. ODESOLA ${ }^{\text {a }}$ \\ ${ }^{a}$ Department of Building, Faculty of Environmental Studies, University of Uyo, Uyo, Nigeria
}

Received 18 February 2014; accepted 9 October 2015

\begin{abstract}
Previous research has acknowledged facilities management (FM) as a discipline that optimises the delivery of facilities and its related services through use of high profile strategies that provide cost effective, high quality and integrated approach to the concept of managing facilities and its related services. The purpose of this paper is to examine the theoretical trends in outsourcing of FM functions and the current state of FM practice using Nigeria and UK as case studies. This research used a combination of literature review and questionnaire survey. The questionnaire survey was conducted to further explore (through comparative analysis) the perception of 30 (15 from UK and 15 from Nigeria) carefully selected facilities managers in UK and Nigeria who are subscribing members of British Institute of Facilities Management (BIFM) and International Facilities Management Association (IFMA) Nigeria's chapter respectively. 22 respondents consisting of 13 received from UK respondents and 9 from Nigeria responded to the survey giving a response rate of $73 \%$. Findings reveal among others that FM has grown from the traditional day-to-day operational management to being a strategic management tool; while janitorial services and facilities maintenance remain the most outsourced FM services.
\end{abstract}

KEYWORDS: Outsourcing; Make or buy; Risks; FM service delivery; Nigeria

\section{INTRODUCTION}

Facilities management (FM) research has continued to attract considerable amount of interest among researchers and practitioners on account of its increasing profile as a significant contributor to the overall effectiveness of organisations notably private and public sector entities in the global economy. Theoretically, it had hitherto been acknowledged by researchers in the field of FM (Nutt 1999) as a discipline in its early stages of development, hardly supported by adequate knowledge base and practical theory, and grossly under-researched. Although Junghans and Olsson (2014) are of the view that FM is characterised by its belonging to non-core business services focusing on workspaces and their management, recent indications point to the fact that it is now becoming a strategic function embedded within the strategic objectives of core business. It is also moving away from previous perception of it as being mainly technically oriented and reactive in nature (Bar-

* Corresponding author. E-mail: isaacikediashi@yahoo.com rett 2000; Grimshaw 2007). In the United Kingdom (UK), FM market is reported to be worth over $\$ 175.6$ billion by 2007 estimate with an anticipated growth forcast in the sector of between $2 \%$ and $3 \%$ up to 2012 (Shah 2007) making it one of the fastest growing professions in Europe. FM practice in Africa is powered mainly by two economic blocs of South Africa and Nigeria. In Nigeria, it is said to be evolving at an exponential rate due to the country's rising profile as one of the fastest growing entities in the emerging market economies (EMEs) and a key player in the international oil industry (Oyedepo 2012). The Nigeria's chapter of the International Facilities Management Association (IFMA) created in 1997 has been at the vanguard of promoting awareness and practice of the profession in Nigeria.

This paper contends that globalisation, sustainability and outsourcing are three main issues that have shaped the advance of FM practice over the past three decades. First, globalisation which describes the integration of national and regional 
economies, societies, and cultures through global network of trade, information and communication technology (ICT), immigration and transportation has transformed the way businesses are run but also led to the emergence of new organisational forms such as Google, EBay, Amazon and YouTube. According to Grimshaw (2006), this global revolution means that FM knowledge must now be underpinned by (1) an understanding of the mathematical principles of how networks operate (2) communications strategies linked to physical structures (3) how offices and facilities can be shaped to promote interaction and creativity (4) an evaluation of the customer experience (5) an understanding of the psychological impact of people on working in isolation (6) how organisational culture is transmitted non-physically and (7) the impact of flexible work on carbon foot prints. Second, sustainability studies continue to attract global attention among researchers in response to the desire to build a humane, equitable, and caring global society, cognizant of the need for human dignity for all (Johannesburg declaration on sustainable development 2002). In that sense, the evolution of sustainable FM practice over the past decades has consistently been driven by the need to contribute in reducing the impact of built environment including construction projects and facilities related services on the environment thereby advancing the sustainability agenda across the three bottom lines of economic, environmental and social sustainability. Third, the impact of globalisation has also exacerbated the rise of outsourcing as a strategy by organisations to diversify their vast network of operations including workspace provision and management that integrates management of process (virtual world), place (physical world) and people (mental world). Researchers and practitioners argue that by bringing in service providers to manage some services for organisations, there is improvement in cost transparency, strategic positioning, and increased access to new technologies, skills, and expertise. The global outsourcing market is reported to have grown from US $\$ 146$ billion in 1996 to an impressive US $\$ 1.3$ trillion in 2007 (IAOP 2012). Several global research agencies including KPMG report (2007), Porter (2007), PricewaterhouseCoopers (2007), and Technology Partners International (TPI 2011) have all reported a growing trend in the volume of outsourcing engagements worldwide in terms of both number of contracts and their average value. Recently, Ernst and Young (2013) reported that the three main reasons why organisations in Eu- rope are outsourcing in 2013 are cost reduction, efficiency improvement and reduction in headcount.

Based on the above background, this paper aims to examine the theoretical trends in facilities management outsourcing by (1) reviewing literature on theoretical trends in FM outsourcing; (2) assessing the global trends in the FM practice since its formation decades ago and (3) conducting a mini comparative survey of UK and Nigeria to ascertain the current state of FM outsourcing in both countries. Finally, the paper presents concluding remarks based on findings from literature review and the questionnaire survey.

\section{LITERATURE REVIEW}

The increasing use of outsourcing for FM services has expanded over the past decades. Researchers have highlighted the complexity of the concept with regards to decision to outsource (make or buy) weighed against inherent risks associated with such decision. Similarly, but to a much lesser extent, scholars have explored the past, present and future of FM. These are indications that an extensive body of literature exists on these two subjects. This section explores the theoretical trends in FM outsourcing and examines the global trend in practice with a view towards documenting the current state of the art and using same as theoretical framework for the questionnaire survey.

\subsection{Theoretical trends in FM outsourcing}

There has been considerable amount of debate within the past decades on the true definition of FM. While it is not our intension to join in the debate, it is important to note that "these definitions have prevented a common platform that is crucial for a cohesive theoretical development in FM" (Tay, Ooi 2001). For example, EN 15221-1 (EN 152211:2006 Facility Management ... 2006) defines FM as "the integration of processes within an organisation to maintain and develop the agreed services which support and improve the effectiveness of its primary activities". On its own part, the International Facilities Management Association (IFMA) defines facilities management as: "the practice of coordinating the workplace with the people and work process of the organisation; integrating the principle of business administration and the behavioural and engineering sciences" (IFMA 2007). A cursory look at these and many other definitions shows widespread variance on the understanding of what facilities management is, how it operates 
and to what extent it offers sustainable opportunities for businesses (Noor, Pitt 2009). That being the case, this paper agrees with the more developed view of FM by Grimshaw (2007) which states that "FM encompasses built environment, technology, management science, and social psychology." This is because with the on-going transformation of how businesses are run today, FM has evolved from being mere facilities maintenance confined to the maintenance unit at the operational level of management, to an integral corporate function tasked with the responsibility of contributing to the delivery of strategic objectives of an organisation over a long term.

Outsourcing on the other hand has been variously described as a management approach that delegates operation and management of activities or functions to specialised agents or providers for components, processes or services hitherto delivered by in-house team (Mclvor 2000; Farrell 2010). The concept of outsourcing has undergone theoretical transformation over the past decades from early resource based view (Wernerfelt 1984) through transaction cost perspective (Williamson 1985), core competency theory (Hamel, Prahalad 1994), agency theory (Eisenhardt 1989) to knowledge based view (Bustinza et al. 2010). According to Wernerfelt (1984), a resource is anything that adds to the strength of an organisation. These resources have the attributes of value, rareness, difficult to imitate and non-substitutability. A resource is considered valuable if it adds to the positive value of the firm, rare if it is unique or scarce among current and potential competitors, difficult to imitate or replicate by competitors and cannot be used in place of it by competing firms to achieve the same or identical results. From a resource based point of view therefore, an organisation is expected to formulate its internal strategy to gain market advantages and capitalize on its internally available resources. Transaction cost economics (Williamson 1985) on the other hand, ensures that economic efficiency is achieved by a comparative analysis of production and transaction costs exchanged between parties to a transaction. In other words, transactions that have low asset specificity, low uncertainty and high frequency of contracting should be outsourced while when the reverse becomes the case, the use of in-house staff is recommended. Core competency theory (Hamel, Prahalad 1994) states that core competencies that provide competitive advantages must be closely protected while the non-core activities are good incentives for outsourcing. This is because outsourcing of core competencies may reduce the incentives in firm innovation, disclosure of critical technologies and patents, and therefore nullify the benefits brought by outsourcing. Proponents of agency theory such as Eisenhardt (1989) argue that it explains the relationship between principals (clients) and its agents (outsourcing vendors). In other words, it is concerned with resolving two problems in any outsourcing relationship:

- The goal of the principal and its agents are in conflict;

- The principal and agent reconcile different tolerances for risk.

Agency theory therefore recognises the presence of risks in outsourcing and offers best mechanism for measuring risk preference more easily and realistically.

It is acknowledged in the literature that considerable emphasis has shifted to knowledge base theory particularly during the past decade driven by increased competitive pressures as globalisation makes innovation absolutely critical (Farrell 2010). Authors such as Spanos and Lioukas (2001) and Powell et al. (2006) also argue that it offers a better theoretical framework to study the sources of sustained competitive advantage and ultimately improve performance. In other words, knowledge management theory views an organisation as a citadel of knowledge whose distinctive resource base enables it to ceaselessly create knowledge, innovative process and products as well as learn from past mistakes.

While outsourcing is not new, a lot have changed with regards to the range of products and services outsourced and the extent to which core or noncore functions are outsourced. Similarly, while it is acknowledged that IT outsourcing has consistently commanded a controlling share of the $\$ 1$ trillion industry, it is to be said that outsourcing of FM services is gradually taking a sizeable portion of the industry. Researchers opine that organisations are keying into this concept of FM outsourcing by planning and reorganising their FM services provision to reflect changes of in-house FM staff from hitherto day-to-day operational tasks to more strategic roles that support the overall goals of their organisations (Ventovuori, Lehtonen 2006). In other words, the responsibility for management of FM services is shifting to either the use of specialist partners (Usher 2004) or the entire package being outsourced to a total facilities management company (Atkin, Brooks 2009); while service providers have begun to redevelop and rebrand their various range of services as a way of attracting interests 
from prospective clients. It is equally important to note that the range of FM services outsourced is gradually shifting from janitorial services such as cleaning, security and catering to more sophiscated functions like property portfolio management, human and environmental management, planning and project management, quality assessment and innovation, communication management, financial management and event management (Chitopanich 2004; EN 15221-4:2011 Facility Management ... 2011; IFMA 2007). This increasing complexity of FM outsourcing has also been accompanied by complex decision making process for organisations. This is because managers are now faced with the protracted "make or buy" decision that will not put them at the risk of loosing their competitive advantage, but also able to develop proactive mitigation measures against identified risks associated with FM outsourcing. A major theoretical revolution is on-going in this regard with authors trying to ascertain the best possible methodology to help practitioners ensure outsourcing success both within the public and private sectors. This is the subject of an on-going research aimed at building a model for outsourcing FM services for public institutions in Nigeria. It hopes to integrate key constructs of decision support system and risk management mechanism into an amalgamated framework as way of maintaining healthy relationships between client organisations and its service providers through the process of negotiations and conflict resolutions and eventual reduction of costs. It is hoped that where there is a possibility for vendors' opportunistic behaviour, relationship and trust building measures, the dos and the don'ts built into the framework can reduce friction, uncertainty and risk. Through the framework also, vendors can know in more detail through the instrumentality of service level agreement (SLA), the expectations of their clients by understanding their relationships and the trust built can provide the platform for better negotiations with clients if and when needed.

It is clear from the above that FM outsourcing has undergone tremendous transformation theoretically over the past decades. What then has been the trend in practice? The next session attempts to provide answer to this.

\subsection{Trends in FM outsourcing practice}

Facilities management as it is known today dates back to the 1800 s when the railway companies in USA conceived the idea of providing facilities- related services as opposed to providing buildings (Atkin 2003). Ever since then, it has witnessed tremendous global transformation entering Europe in the mid 1980s first in UK in 1984, the Netherlands in 1986, the Scandinavian countries in 1992 and Germany in 1995 (Levainen 1997). As a follow up to this, a non-profit organization called International Facilities Management Association (IFMA) was established in the early 1980 s to incorporate associations dedicated to serving the FM profession originally in North America; but as of today has members represented globally in over 60 countries worldwide (Ventovuori 2007). Since it entered Europe, several organisations have sprung up to project the image of FM. Some of them include the Nordic FM, the British International Facilities Management Association (BIFMA), Finland Facilities Management association (FIFMA), European FM (EuroFM), and German Facilities Management Association (GEFMA). According to the European Committee for standardization, FM is gaining foothold across Europe on account of the increasing complexities occasioned by historical and cultural circumstances and exacerbated by the need to optimize cost and performance of assets and services be it public or private (Booth 2013).

It is to be acknowledged that since its formation, FM is said to have transformed from mere janitorial services, to becoming an integral part of the boardroom management. Accordingly and in line with the trends, FM practice is now distinguished into two purposes namely short term operational FM and longer term strategic FM. Short term operational level, described as the most visible part of FM involves day-to-day provision of safe and efficient working environment for an organisation core business activities to thrive (Nutt 1999). It involves such services as cleaning, provision of security services and other janitorial services. From the perspective of FM as a short term operational support service, Chitopanich (2004) argues that the primary function of FM is to handle and manage support services to meet the needs of the organization, its core operations and employees. In other words, it is a support function coordinating physical resources and workplace, and support services to user and process of works to support the core business of the organization. In an effort to develop a synchronized list of FM services, Chitopanich (2004) after reviewing a list of support services within the FM remit from previous authors, evolved a cluster of support services that can give a generic scope of FM services. It is made up of five main components namely real estate and property 
management, maintenance and repairs, office services, space planning and management as well as employee supports and services.

One of the major transformations in FM practice in Europe within the past decade has been the development of EN 15221 standard. According to Steenhuizen et al. (2014), it was commissioned by the European Committee for Standardization CEN/TC 348 - Facility Management to provide a common platform across Europe for identifying the scope of FM in terms of space and infrastructure and people and organisation. The standard consists of seven parts as shown in Table 1.

The first set of standards deals with terms and definitions of FM (EN 15221-1:2006 Facility Management ... 2006) while the second focuses on guidance on how to prepare FM agreements ( $E N$ 15221-2:2006 Facility Management ... 2006) also known SLAs. These two were developed in 2006 and accepted by 30 participating countries across Europe (Mitchell 2006). The five other parts were established to provide guidance on (1) how to achieve quality in FM including how quality measurement methods could contribute to the interaction between primary activities and FM processes (EN 15221-3:2011 Facility Management ... 2011); (2) classification and structures or taxonomy of FM (EN 15221-4:2011 Facility Management ... 2011); (3) development and improvement of FM processes including process mapping and protocols (EN 15221-5:2011 Facility Management ... 2011); (4) development of a European standard in terms of accuracy, protocol and usage of space ( $E N$ 15221-6:2011 Facility Management ... 2011); and (5) establishes a common basis for benchmarking facility management costs, floor areas and environmental impacts as well as service quality, satisfaction and productivity (EN 15221-7:2012 Facility Management ... 2012). This continuous cycle of FM provision is epitomised in the famous European FM model in Figure 1.

The model specifically identifies three levels of FM process as strategic, tactical and operational.

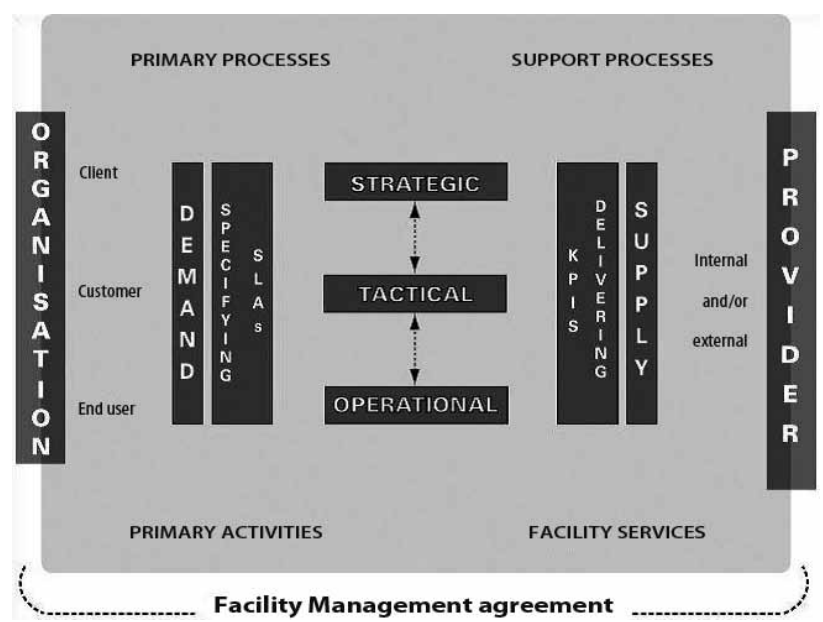

Fig. 1. European FM model adapted from EN 152211:2006 Facility Management ... (2006)

FM on the strategic level involves aligning with the higher level of management to deliberate on corporate decisions that will ensure that facilities meet clearly defined business objectives on a long term basis. According to Chitopanich (2004), such strategic decisions involve issues on property asset portfolio management, strategic property decisions and facilities planning and development which are related to policy and strategic plan of the organization. On the other hand, tactical FM involves monitoring, controlling and managing the operational functions of FM to ensure they are being done in accordance with organization's standards as it relates to policies, strategies and plan. The operational function involves short term results on a day-to-day level and is the most visible part of FM. It supports the basic routine and regular needs of the organization.

It is worth mentioning that researchers such as Jack (1994), Pitt and Hinks (2001), Chitopanich (2004), Yiu (2008) and CEN/TC 348 (2016) have all emphasized the evolving trends of facilities management as a strategic tool in organisations. The general conclusion drawn from these authors is that there is the need to incorporate FM into the strategic management level of organisations

Table 1. CEN/TC 348 Published Standards (CEN/TC 348 2016)

\begin{tabular}{lcll}
\hline Reference & Part & Title \\
\hline EN 15221-1:2006 & 1 & Facility Management - Part 1: Terms and definitions \\
EN 15221-2:2006 & 2 & Facility Management - Part 2: Guidance on how to prepare Facility Management agreements \\
EN 15221-3:2011 & 3 & Facility Management - Part 3: Guidance on quality in Facility Management \\
EN 15221-4:2011 & 4 & Facility Management - Part 4: Taxonomy, Classification and Structures in Facility Management \\
EN 15221-5:2011 & 5 & Facility Management - Part 5: Guidance on Facility Management processes \\
EN 15221-6:2011 & 6 & Facility Management - Part 6: Area and Space Measurement in Facility Management \\
EN 15221-7:2012 & 7 & Facility Management - Part 7: Guidelines for Performance Benchmarking \\
\hline
\end{tabular}


to bring about the anticipated strong commitment towards sustainable FM practice. This is arguably because strategic FM manages and coordinates work environment and support services in such strategic areas as property asset management, strategic property decision and facilities planning and development, all related to policy and strategic action plan of an organisation. With the increasing complexities of properties and management of its related services, facilities managers are now involved at the top level of management on the long term understanding of the broader context in which facilities are operated.

Regarding structure of FM process, Barrett and Baldry (2003) developed a model of 5 organisational structures that has evolved over the years of facilities management practice. The first category, Office manager model involves a part time assignment of a facilities manager as part of general duties. The person who may not be technically oriented or actively involved in the core function of the organisation oversees occasional facilities functions and repairs as the need arises. It was popular in the early stages of FM and suitable for small organisations. Single site model is popular in organisations in one locality but able to create a separate FM unit responsible for management of its assets. The organisation uses both in-house team and service providers to execute its functions. The model is common with middle size organisations such as manufacturing plants and independent retail outlets. Localised site model is common in organisations with facilities in different locations coordinated from one site headquarter office. A distinct feature of this model is the decentralisation of operations allowing smaller sites to take some certain level of decision while major policy decisions are taking at the central management level. Multi sites model operates a system of multiple locations spread across several geographical locations within the same nationality but however performing similar functions in each location through a dedicated FM office while its activities are coordinated at the strategic level. It is suitable for large organisations with large national and international spread such as hospitals (NHS in UK for instance), multinational companies and major banking institutions. The fifth category is the International model. It is similar in many respects to the multi sites model but operates across different countries. It does this through partnering with off shoring outsourcing vendors who have the requisite knowledge and ability to integrate properly in terms of language and legislation with concerned countries.
To also buttress the changing face of FM, Jensen (2008) carried out an explorative case study on the origin and constitution of FM as an integrated corporate function using Danish Broadcasting Corporation's 80 years existence as a corporate function. The study shows a patterned growth of the corporation's FM unit from an ordinary administration office that coordinates all service and building related functions in 1951 to becoming one integral unit for administration office matters and building coordination activities. In conclusion, Jensen (2008) stated that "the development clearly shows the need for a coherent strategic planning of the development of the corporation and corporate facilities. This is important both for the corporation to achieve its objectives and for the FM function to act proactive and professional. This implies that building client function in general should be an integrated part of the FM function". It is equally said that integration of FM function was established to make the organisation more customer oriented and to reduce cost which are hallmarks of outsourcing.

In terms of market size, Table 2 adapted from Teichmann (2009) indicates that as at 2009, UK had the largest share of FM market in Europe with a worth of 204 billion euros, closely followed at the second and third by German and France with estimates of 74 billion euros and 59 billion euros respectively. It is also worth stating that in another study by Jensen (2010), Swedish FM market had the largest market size of 23 billion

Table 2. FM market size in Europe

\begin{tabular}{llll}
\hline $\begin{array}{l}\text { Rank in } \\
\text { Europe }\end{array}$ & Country & $\begin{array}{l}\text { Market size } \\
\text { (billion euros) }\end{array}$ & $\begin{array}{l}\text { \% of total } \\
\text { European } \\
\text { market }\end{array}$ \\
\hline 1 & UK & 204.39 & 31.20 \\
2 & Germany & 73.38 & 11.20 \\
3 & France & 58.89 & 8.99 \\
4 & Italy & 48.78 & 7.45 \\
5 & Spain & 37.31 & 5.70 \\
6 & Russia & 31.76 & 4.85 \\
7 & Netherlands & 25.93 & 3.96 \\
8 & Belgium & 15.41 & 2.35 \\
9 & Switzerland & 15.25 & 2.33 \\
10 & Turkey & 15.10 & 2.30 \\
20 & Czech Republic & 5.15 & 0.79 \\
28 & Belarus & 1.23 & 0.19 \\
41 & Montenegro & 0.09 & 0.014 \\
Total size & & 655.13 & 100 \\
of Euro- & & & \\
pean FM & & & \\
market & & &
\end{tabular}

Source: Teichmann (2009). 
euros in the Nordic countries while the FM market was worth 12 billion euros in Finland, 9 billion euros in Norway, and 8 billion euros in Denmark. Besides, the degree of FM outsourcing is reported to have increased from $58 \%$ in 2000 to $63 \%$ in 2007 . All of these point to the fact that FM outsourcing is also undergoing tremendous transformation in Europe.

On account of the increasing competitiveness and globalisation, FM has embraced innovative skills through not just delivery of services in the most effective way, but by providing them in an ever changing world over the years (Noor, Pitt 2009). This has triggered diverse forms of delivery options including use of FM contractors, in-house teams, FM outsourcing vendors, consultants and professional institutions. Though relatively new compared to IT outsourcing, FM outsourcing has been expanding since the 1990s (Brochner et al. 2001) enabling organisations to respond to environmental uncertainties in ways that do not increase costs associated with internal bureaucracy and focusing on building their core competencies. It has come in several packages such as managing agent, managing contractor and total facilities management contractor while their application is dependent on type, philosophy and objectives of the organisation (Atkin, Brooks 2009). Another dimension worthy of mention is the demand perspective of FM value proposed by Coenen et al. (2013) in which the authors analysed the concept of FM from value perspective by considering client, customer, and end-user perception of value. They concluded that FM value network considers FM as an open system of relationships built through the co-creation of services, through integration of resources and through effective communication. In other words, FM is now encompassing the demand side of service as demonstrated in the European FM model.

The review above shows that FM as part of the global business model has continued to explore how organisation can grow faster through expansion into new markets, find new ways of fostering innovation through collaborative outsourcing that will achieve right balance between the decision to outsource, risks and legal requirements embedded in the service level agreement (SLA) between client organisations and their FM outsourcing vendors.

The next section presents research methods deployed for the mini questionnaire survey conducted to further explore how FM outsourcing has evolved overtime in Nigeria and UK. As noted in the introductory background, UK registers as one of the countries where FM is projected to be one of the fastest growing professions in Europe while FM practice in Nigeria is said to be evolving at an exponential rate due to the country's rising profile as one of the fastest growing entities in the emerging market economies (EMEs) and a key player in the international oil industry (VETIVA 2011; Oyedepo 2012).

\section{METHODOLOGY}

Having reviewed major theoretical trends and practice of FM outsourcing, a questionnaire survey was conducted to further explore the state of FM practice (through comparative analysis) in UK (the largest FM market in Europe) and Nigeria (an emerging and one of the fastest growing economies in Africa).

In order to explore the current state of FM practice in both countries, taxonomy of $12 \mathrm{key}$ variables comprising one question for state of FM practice, 5 factors for FM services and 6 motives for outsourcing FM services, was developed from the literature review and pilot-tested using academic experts and FM practitioners in both countries. Copies of the draft questionnaire were sent to academic experts while personal interview section was organised with a focus group of four FM practitioners from the IFMA, Nigeria's chapter with a view towards scrutinising contents of the questionnaire. The academic experts are renowned researchers in the area of outsourcing while the FM practitioners are full time facilities managers registered with IFMA, Nigeria's chapter with over 20 years' experience in FM. It is important to emphasise at this point that this study focused on the 6 support services based on the recommendation of the experts and practitioners. They argued that since the comparative investigation involves a developing country, it would be unwise to enlist the FM services not common in the developing economies.

This approach purposely targeted 30 (15 from UK and 15 from Nigeria) carefully selected facilities managers who are subscribing members of British Institute of Facilities Management (BIFM) and International Facilities Management Association (IFMA) Nigeria's chapter respectively. They were selected through purposive sampling technique based on their track record of practice and knowledge about the concepts under investigation. Request for consent was first sent to the respondents through email before questionnaire consisting 
of 12 variables in 8 closed ended questions was sent to them.

The questionnaire was in four parts. Part 1 sought general background information about respondents while part 2 asked respondents to rate the current state of FM practice in their various country of practice using the scale of $1=$ excellent, $2=$ very good, $3=$ adequate, and $4=$ inconsistent. In part 3 , respondents were asked to indicate as appropriate component of FM services most commonly outsourced in their organisations using the scale of $1=$ very low, $2=$ low, $3=$ somehow high, $4=$ high, and $5=$ very high. In part 4 , respondents were asked to indicate the degree to which the list motives for outsourcing have affected the decision to outsource FM services in their organisations using the scale of $1=$ strongly disagree, $2=$ disagree, $3=$ somehow agree, $4=$ agree, and $5=$ strongly agree.

Twenty-two (22) respondents consisting of 13 received from UK respondents and 9 from Nigeria responded to the survey giving a response rate of $73 \%$. Despite the relatively small size of sample (22), the quality of response is deemed reliable for analysis in this research due to the calibre of respondents in terms of years of experience with outsourcing of FM services, relevant professional pedigree as well as clear understanding of constructs used in the study.

Data collected were analysed using basic descriptive statistics while Mann Whitney U test and one way analysis of variance (ANOVA) were used for difference in response analysis. Mann Whitney U-test, a non-parametric test, has the obvious advantage of not possessing restrictive assumptions of normality or homogeneity of variance (Ikediashi et al. 2012).

\section{ANALYSIS OF RESULTS AND DISCUSSION OF FINDINGS}

\subsection{Demographics of respondents}

The survey results showed that a combined 16 of the 22 respondents are corporate members of BIFM and IFMA, Nigeria chapter, 4 are fellows while 2 are associate members. In terms of FM experience, 10 have had between 20 and 30 years working experience, 9 have had between 10 and 20 years, 2 have had over 30 years, while only 1 respondent have had less than 10 years experience. Furthermore, 7 respondents worked in financial/ business support service companies, 4 worked in manufacturing/engineering companies, 3 worked in healthcare; another 3 worked in government/ public sector establishment, 2 worked in major retail outlets while 1 respondent each worked in educational, oil exploration and oil servicing organisations. This represents an indication that (1) there is a good spread of respondents across a spectrum of different organisations; (2) respondents are well respected members of their chosen professional affiliates; and (3) they have the requisite knowledge and professional pedigree about general views and wants of FM profession. It is important to also add that all respondents have worked with FM service providers for outsourcing of FM functions.

\subsection{State of FM practice in UK and Nigeria}

Figure 2 indicates that out of the 13 (59\%) who responded from UK, 10 rated the state of FM practice as "very good", 2 rated it as "adequate" while 1 rated it as "excellent". In marked contrast, out of 9 (41\%) who responded from Nigeria, 3 rated the state of FM practice in Nigeria as "very good", the same number of 3 respondents rated it as "adequate" and "inconsistent".

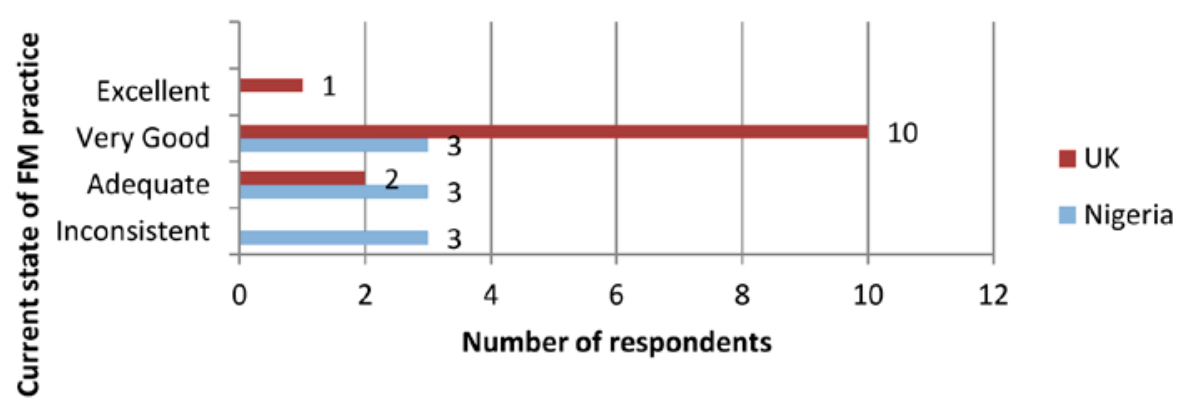

Fig. 2. Comparative analysis of state of FM practice in Nigeria and UK 


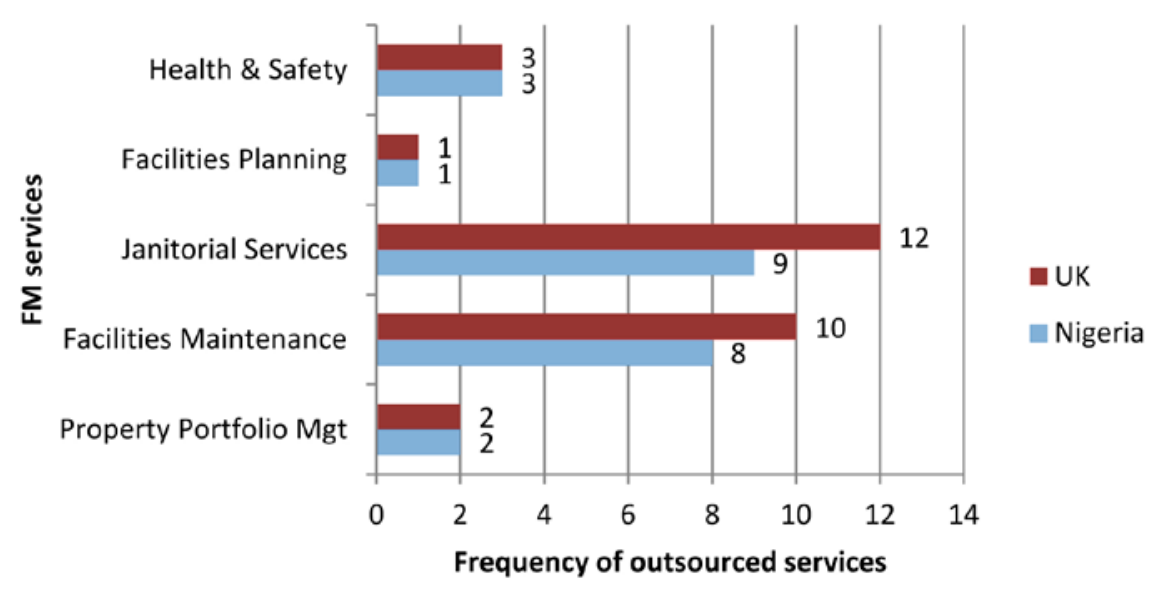

Fig. 3. Result of response on outsourced FM services

\subsection{Outsourced FM functions in organisations}

On the issue of outsourced services in organisations, respondents were asked to indicate FM services currently being outsourced in their organisations, with each respondent given the option of indicating more than 1 of the 5 listed FM services.

Figure 3 shows that 12 or $92 \%$ of respondents from UK affirmed that janitorial services are outsourced in their organisations while all respondents from Nigeria (9 of them) indicate that janitorial services are outsourced in their organisations. Furthermore, 10 or $77 \%$ of 13 UK based respondents reported that facilities maintenance is outsourced in their organisations while 8 or $89 \%$ of respondents from Nigeria reported that facilities maintenance is outsourced in their organisations. However, while 3 each from Nigeria and UK indicated that Health and safety are outsourced in their organisations, 2 each also indicated that Property portfolio management are outsourced in their organisations.

\subsection{Motives for outsourcing}

Results of analysis shown in Table 3 indicate that to "focus on core competency", "to access vendor's innovative skills and expertise", and "quality considerations" were the top three rated motives in Nigeria, UK and on the average.

The result also shows that cost considerations, competitive advantage and corporate social responsibility were the three least rated motives for outsourcing on the average.
Table 3. Result of analysis for motives for outsourcing FM services

\begin{tabular}{|c|c|c|c|c|c|c|}
\hline \multirow{2}{*}{$\begin{array}{l}\text { Motives for } \\
\text { outsourcing }\end{array}$} & \multicolumn{2}{|l|}{ UK } & \multicolumn{2}{|c|}{ Nigeria } & \multicolumn{2}{|c|}{ Average } \\
\hline & Mean & Rank & Mean & Rank & Mean & Rank \\
\hline $\begin{array}{l}\text { Cost consid- } \\
\text { erations }\end{array}$ & 3.7 & 4 & 3.3 & 4 & 3.6 & 4 \\
\hline $\begin{array}{l}\text { Competitive } \\
\text { advantage }\end{array}$ & 3.4 & 5 & 2.1 & 6 & 2.7 & 5 \\
\hline $\begin{array}{l}\text { Quality con- } \\
\text { siderations }\end{array}$ & 3.8 & 3 & 4.1 & 3 & 3.9 & 3 \\
\hline $\begin{array}{l}\text { Focus on core } \\
\text { competency }\end{array}$ & 4.5 & 1 & 4.6 & 1 & 4.5 & 1 \\
\hline $\begin{array}{l}\text { To access in- } \\
\text { novative skills }\end{array}$ & 4.2 & 2 & 4.2 & 2 & 4.2 & 2 \\
\hline $\begin{array}{l}\text { Corporate } \\
\text { social respon- } \\
\text { sibility }\end{array}$ & 2.0 & 6 & 2.2 & 5 & 2.1 & 6 \\
\hline
\end{tabular}

\subsection{Agreement analysis}

Two tests were conducted to examine the degree of agreement in the responses as shown in Table 4. One way analysis of variance (ANOVA) was used to establish whether there is any difference in response based on their groupings such as professional affiliation, work experience and type of organisation; while Mann Whitney $U$ test was used to examine the degree of agreement among responses from Nigeria and UK. All tests were carried out at $5 \%$ significance difference meaning that all $p$ values less than 0.05 are significant $(p<0.05)$.

Result indicates that respondents generally agree in their perceptions about motives for outsourcing as only in one instance (focus on core competency) does there seem to be significant difference. There is however significant difference in 
Table 4. Result of difference in response analysis

\begin{tabular}{lllll}
\hline & \multicolumn{2}{l}{ Mann Whitney } & \multicolumn{2}{l}{ One way ANOVA } \\
\cline { 2 - 5 } & Nigeria/UK & Professional A & Work experience & Type of org. \\
\cline { 2 - 5 } & U p-value & F p-value & F p-value & F p-value \\
\hline State of FM practice & 24.00 .19 & $6.990 .01^{*}$ & $4.550 .02^{*}$ & $1.320 .03^{*}$ \\
Motives for outsourcing & & & & \\
Cost considerations & 42.50 .27 & 0.560 .58 & 0.990 .42 & 1.910 .14 \\
Competitive advantage & 31.50 .06 & 1.660 .22 & 0.390 .76 & 0.820 .58 \\
Quality considerations & 35.50 .07 & 1.380 .28 & 0.080 .97 & 0.970 .49 \\
Core competency & 55.50 .82 & 0.770 .48 & 0.790 .51 & $3.100 .04^{*}$ \\
Innovative skills & 53.00 .64 & 1.050 .37 & 1.030 .40 & 1.090 .42 \\
CSR & 40.00 .18 & 0.170 .85 & 0.120 .95 & 2.570 .06 \\
\hline
\end{tabular}

Note: $\mathrm{CSR}=$ corporate social responsibility; $\mathrm{A}=$ affiliation; $\mathrm{U}=\mathrm{U}$ test statistic.

the responses about the state of FM practice as ANOVA result indicates a dissimilarity in their responses across the three groupings. The implication is that while most of all the respondents have similar views on the motives for outsourcing FM services, there is dissenting opinion among them about the state of FM practice.

\subsection{Discussion of findings and implications}

Findings confirm that the state of FM practice in UK has developed considerably compared to other countries in Europe and Africa. For instance, it is consistent with findings of Teichmann (2009) and Steenhuizen et al. (2014). Both studies adduced to the fact that the facilities management market in UK remains the largest and most successful. Although the huge disparity in the findings above is widely expected, it is conceivable to state that $\mathrm{Ni}$ geria has much to get by leveraging on the success of FM as a profession in UK and other Western countries such as US, Australia, New Zealand, and Hong Kong where it is already well established. It also stands to benefit from other markets such as those of German, the Benelux countries, and some of the east European countries such as Poland, Czech Republic and Slovenia. According to Interconnection (2014), the recent economic recession across Europe has boosted the outsourcing of facility services in Eastern Europe where it has caused a decline in spending and a higher price sensitivity resulting in measures of cost cutting. As it stands, almost $70 \%$ of all its FM services in Nigeria's public and private sector are still operated by in-house staff.

Findings also reveal that janitorial services as the most outsourced component of FM services in Nigeria and UK, followed by facilities maintenance. However, the result indicates that most organisations prefer to leave health and safety, facilities planning and property portfolio management to their in-house teams. This is consistent with most reports (Deloitte 2014; Interconnection 2014) which have indicated that such services as security, catering, cleaning, laundry and technical maintenance usually described as soft FM are the most outsourced components of FM. Giving the evolving nature of outsourcing and the apparent apprehension towards the concept by the workforce in Nigeria, the government and other stakeholders would need to carry out orientation and sensitization workshops to assure workers and other stakeholders about the benefits and risks of outsourcing generally and FM in particular.

With regards to motives for outsourcing, "focus on core competency", "to access vendor's innovative skills and expertise", and "quality considerations" were the top three rated. Curiously, cost consideration was not considered a top priority by respondents. This is inconsistent with many previous studies that have reported cost as the main driver for outsourcing. The practical implication is that organisations now prefer to concentrate on their primary core competencies as the main reason for outsourcing. In other words, as the practice of FM is becoming increasingly complex, most organisations are taking that strategic decision to bring in competent vendors with the requisite skills and expertise to manage their FM portfolios to enable them concentrate on their core areas of competitive advantage. Surprisingly, CSR was the least rated of the 6 motives of outsourcing. The current argument in the literature is that FM adds to value, not only by increasing the economic viability of business development but also by delivering social and environmental benefits. Such social benefits include all forms of corporate social responsibility 
(CSR) for the common good of the public such as provision of good jobs, social amenities, and promotion of healthy living (Alexander, Brown 2006). This is however contrary to reports from Nigeria which indicated that most organisations are outsourcing some of their non-core functions to local vendors as a way of empowering the local community in which organisations are situated. This has profound implication for practice. In Nigeria, FM is widely practiced in government agencies, local and foreign multi-nationals as well as non-governmental, non-profit organisations spread across the six geopolitical zones in the country. Many of them are reported to have incorporated CSR into their policy agenda which afford them the opportunity to embark on social projects around the community within which they operate. A good explanation for this outcome might be that the use of outsourcing for CSR is not making the required impact in Nigeria.

\section{CONCLUSIONS}

The primary aim of this study is to analyse the current trends in FM outsourcing using both theoretical and practical underpinnings. A mini questionnaire survey was then conducted to analyse the current state of FM practice in Nigeria and United Kingdom. Taxonomy of 12 key variables were extracted from the literature while target respondents for the survey, who were purposely selected based on their track records of service are top level FM practitioners in the two countries. Their responses were analysed using descriptive and inferential statistical tools.

Findings reveal that FM has been and will continue to be at the front burner of modern research tradition on account of its strategic significance in the management of facilities and its related services. Besides, research indicates that with the growing maturity and public recognition of the FM industry as well as the diversity of interests and factors shaping FM outsourcing and sustainable FM practice, employer demand for top class facilities managers has increased. This has exacerbated the emergence of FM as an academic discipline in several Universities across the globe. Findings from questionnaire survey reveal that the state of FM practice in UK is good compared to Nigeria while janitorial services and facilities maintenance remain the most outsourced FM services across the two countries. It was also revealed that the most influential motive for out- sourcing FM services is to enable organisations focus on core competencies.

The future of FM practice is significantly bright. However, concerns raised by FM companies in several parts of Europe about the apparent shortage of personnel means that the "war on talent hunt" should be fought with highest sense of vigour. Universities and FM associations should be encouraged to step up skill acquisition and development while the current situation whereby the level of standardisation of FM market is fragmented should be harmonised to reduce variations currently being experienced in language, data collection, terminology and definition of terms. This would benefit such countries as Nigeria where it is at the evolving stages of development.

The questionnaire survey component of this research has an obvious limitation. It was conducted using only 22 samples. It is therefore quite likely that generalisation would be difficult. Further studies could consider using larger samples while more inclusive populations from such regions as United States of America and Asian countries should also be used to examine the impact of outsourcing on the practice of FM.

\section{REFERENCES}

Alexander, K.; Brown, M. 2006. Community-based facilities management, Facilities 24(7/8): 250-268. http:// dx.doi.org/10.1108/02632770610666116

Atkin, B. 2003. Contracting-out or managing services inhouse, Nordic Journal of Surveying and Real Estate Research 1: 18-33.

Atkin, B.; Brooks, A. 2009. Total facilities management. $3^{\text {rd }}$ ed. New York: Wiley-Blackwell Publishers.

Barrett, P. 2000. Achieving strategic facilities management through strong relationships, Facilities 18(10/11/12): 421-426.

Barrett, P.; Baldry, D. 2003. Facilities management: towards best practices. London: Blackwell Publishing.

Booth, N. 2013. A brief history of facilities management [online]. Neville Booth facilities management. Available at: http://nevillebooth.blogspot.co.uk/2013/01/abrief-history-of-facilitiesmanagement [accessed 4 September 2014]

Brochner, J.; Adolfsson, P.; Johansson, M. 2001. Outsourcing facilities management in the process industry: a comparison of Swedish and UK patterns, Journal of Facilities Management 1(3): 265-271. http:// dx.doi.org/10.1108/14725960310807953

Bustinza, O. F.; Molina, L. M.; Gutierrez-Gutierrez, L. J. 2010. Outsourcing as seen from the perspective of knowledge management, Journal of Supply Chain Management 46(3): 23-39. http://dx.doi.org/10.1111/ j.1745-493X.2010.03196.x 
CEN/TC 348. 2016. CEN/TC 348 - Facility Management. Published Standards [online]. European Committee for Standardization CEN/TC 348 - Facility Management. Available at: https://standards.cen.eu/ dyn/www/f?p=204:32:0::::FSP_ORG_ID,FSP_LANG_ ID:414882,25\&cs=1E1EAB55C929B498CC3A8D 420 26DF59BD (accessed 21 January 2016)

Chitopanich, S. 2004. Positioning facilities management, Facilities 22(13/14): 364-372. http://dx.doi. org/10.1108/02632770410563086

Coenen, C.; Alexander, K.; Kok, H. 2013. Facilities management dimension from demand perspective, Journal of Facilities Management 11(4): 339-353. http:// dx.doi.org/10.1108/JFM-10-2012-0049

Deloitte. 2014. 2014 Global outsourcing and insourcing survey results [online]. Deloitte Consulting LLP. Available at: www.deloitte.com [accessed 5 September 2014]

Eisenhardt, K. M. 1989. Agency theory: an assessment and review, Academy of Management Review 14(1): $57-74$.

EN 15221-1:2006 Facility Management - Part 1: Terms and definitions. European committee for standardization. Brussels, 2006.

EN 15221-2:2006 Facility Management - Part 2: Guidance on how to prepare Facility Management agreements. European committee for standardization. Brussels, 2006.

EN 15221-3:2011 Facility Management - Part 3: Guidance on quality in Facility Management. European committee for standardization. Brussels, 2011.

EN 15221-4:2011 Facility Management - Part 4: Taxonomy, Classification and Structures in Facility Management. European committee for standardization. Brussels, 2011.

EN 15221-5:2011 Facility Management - Part 5: Guidance on Facility Management processes. European committee for standardization. Brussels, 2011.

EN 15221-6:2011 Facility Management - Part 6: Area and Space Measurement in Facility Management. European committee for standardization. Brussels, 2011.

EN 15221-7:2012 Facility Management - Part 7: Guidelines for Performance Benchmarking. European committee for standardization. Brussels, 2012.

Ernst and Young. 2013. Outsourcing in Europe: an indepth review of drivers, risks, and trends in the European outsourcing market. London: EYGM Limited.

Farrell, M. 2010. Developing a framework for measuring outsourcing performance, in LRN conference 2010, University of Leeds, Institute for Transport Studies and CILT (UK), 1-8.

Grimshaw, B. 2006. Mobility and change management, in Haugen, T.; Moum, A.; Brochner, J. (Eds.). Proceedings of CIB W70 International Symposium on Changing User Demand on Buildings, 12-14 June 2006, Trondheim, Norway.

Grimshaw, B. 2007. History is bunk: considerations on the future of FM, Facilities 25(11/12): 411-417. http://dx.doi.org/10.1108/02632770710822526
Hamel, G. K.; Prahalad, C. K. 1994. Competing for the future. Boston, MA: Harvard Business School Press.

IAOP. 2012. The global outsourcing 100 [online]. International Association of Outsourcing Professionals (IAOP). Available at: www.iaop.org [accessed $10 \mathrm{Au}-$ gust 2013]

IFMA. 2007. A competency framework for facilities management [online]. International Facilities Management Association (IFMA). Available at: www.ifma. org [accessed 29 January 2011]

Ikediashi, D. I.; Ogunlana, S. O.; Boateng, P.; Okwuashi, O. 2012. Analysis of risks associated with facilities management outsourcing: a multivariate approach, Journal of Facilities Management 10(4): 301-316. http://dx.doi.org/10.1108/14725961211265756

Interconnection. 2014. Economic recession boots outsourcing trends of facility services in Eastern Europe [online]. Interconnection Consulting. Available at: www.interconnectionconsulting.com [accessed 4 September 2014]

Jack, J. 1994. Strategic facilities management, Property Management 12(4): 40-43. http://dx.doi. org/10.1108/02637479410071063

Jensen, P. A. 2008. The origin and constitution of facilities management as an integrated corporate function, Facilities 26(13/14): 490-500. http://dx.doi. org/10.1108/02632770810914253

Jensen, P. A. 2010. The facilities management market in Denmark, Facilities 28(7/8): 383-394. http://dx.doi. org/10.1108/02632771011042482

Johannesburg declaration on sustainable development. 2002. United Nation world summit on sustainable development, 2-4 September 2002.

Junghans, A.; Olsson, N. O. E. 2014. Discussion of facilities management as an academic discipline, Facilities 3(1/2): 67-69. http://dx.doi. org/10.1108/F-10-2012-0078

KPMG report. 2007. Asia Pacific - who is conducting the orchestra. Amstelveen: KPMG International.

Levainen, K. I. 1997. Building sites as a city facility. Facilities management: European practice. Netherlands: Arko Publishers, 44-47.

Mclvor, R. 2000. A practical framework for understanding the outsourcing process, Supply chain management: an international journal 5(1): 22-36.

Mitchell, S. 2006. Standards in facilities management [online]. Available at: www.keyfm.co.uk [accessed 4 September 2014]

Noor, M. N. M.; Pitt, M. 2009. A critical review on innovation in facilities management service delivery, Facilities 27(5/6): 211-228. http://dx.doi. org/10.1108/02632770910944943

Nutt, B. 1999. Linking FM practice and research, Facilities 17(1/2): 11-17. http://dx.doi. org/10.1108/02632779910248406

Oyedepo, S. O. 2012. On energy for sustainable development in Nigeria, Renewable and Sustainable Energy Reviews 16: 2583-2598. http://dx.doi.org/10.1016/j. rser.2012.02.010 
Pitt, M.; Hinks, J. 2001. Barriers to the operation of the facilities management: property management interface, Facilities 19(7/8): 304-307. http://dx.doi. org/10.1108/02632770110390784

Porter, K. 2007. Gartner on outsourcing (2007-2008). Stamford: Gartner Research.

Powell, T. C.; Lovallo, D.; Caringal, C. 2006. Causal ambiguity, management perception, and firm performance, The Academy of Management Review 31(1): 175-196. http://dx.doi.org/10.5465/ AMR.2006.19379630

PricewaterhouseCoopers. 2007. New 2007 global outsourcing survey [online]. Available at: www.dmreview.com/news/1085042-1.html [accessed 12 February 2014]

Shah, S. 2007. Sustainable practice for the facilities manager. Oxford: Blackwell Publishing. http://dx.doi. org/10.1002/9780470759677

Spanos, Y. E.; Lioukas, S. 2001. An examination into the causal logic of rent generation: contrasting Porter's competitive strategy framework and the resource based perspective, Strategic Management Journal 22(10): 907-934. http://dx.doi.org/10.1002/smj.174

Steenhuizen, D.; Flores-Colen, I.; Reitsma, A. G.; Branco Ló, P. 2014. The road to facility management, Facilities 32(1/2): 46-57. http://dx.doi. org/10.1108/F-09-2012-0072

Tay, L.; Ooi, J. T. L. 2001. Facilities management: a jack of all trades?, Facilities 19(10): 357-362. http:// dx.doi.org/10.1108/EUM0000000005534
Teichmann, S. 2009. FM market size in Europe, EuropeanFM Insight, 5-7.

TPI. 2011. TPI momentum market trends and insights 2011 Vertical report. Technology Partners International (TPI), Scottsdale, AZ.

Usher, N. 2004. Outsource or in-house facilities management: the pros and cons, Journal of Facilities Management 2(4): 351-359. http://dx.doi. org/10.1108/14725960410808311

Ventovuori, T. 2007. Analysis of supply models and FM service market trends in Finland, Journal of Facilities Management 5(1): 37-48. http://dx.doi. org/10.1108/14725960710726337

Ventovuori, T.; Lehtonen, T. 2006. Alternative models for management of FM services, Facilities 8(2): 7390. http://dx.doi.org/10.1108/14630010610679880

VETIVA. 2011. Construction industry report: a haven of opportunities. VETIVA Capital Management Limited.

Wernerfelt, B. 1984. A resourced based view of the firm, Strategic Management Journal 5(2): 171-180. http:// dx.doi.org/10.1002/smj.4250050207

Williamson, O. E. 1985. The economic institutions of capitalism. New York: Free Press.

Yiu, C. Y. 2008. A conceptual link among facilities management, strategic management and project management, Facilities 26(13/14): 510-521. http://dx.doi. org/10.1108/02632770810914262 